\title{
Crystal and magnetic structure of substituted lanthanum cobaltites
}

\author{
R. Sonntag ${ }^{a * *}$, S. Neov ${ }^{b}$, V. Kozhukharov ${ }^{b}$, \\ D. Neov ${ }^{\mathrm{b}}$, J.E. ten Elshof ${ }^{\mathrm{c}}$ \\ "Hahn-Meitner-Institut Berlin. Glienicker Str: 100, D-14109 Berlin, Germumy \\ ${ }^{\mathrm{b}}$ Institute for Nuclear Research and Nuclear Energy: 1784-Sofia, Bulgaria \\ "Unitersity of Twente. P.O. Box 217, 7500 AE Enschede. The Netherlands
}

\begin{abstract}
The crystal and magnetic structures of the lanthanum cobaltites $\mathrm{La}_{0.6} \mathrm{Sr}_{0.4} \mathrm{CoO}_{3}, \mathrm{La}_{0.6} \mathrm{Sr}_{0.4} \mathrm{Co}_{0.9} \mathrm{Fe}_{0.1} \mathrm{O}_{3}$ and $\mathrm{La}_{0.6} \mathrm{Ba}_{0.4} \mathrm{Co}_{0.4} \mathrm{Fe}_{0.1} \mathrm{O}_{3}$ have been studied by neutron powder diffraction at temperatures of 2,300 and $900 \mathrm{~K}$. All compounds undergo a phase transition from cubic to rhombohedral structure. Below the room temperature $\mathrm{La}_{0.6} \mathrm{Sr}_{0.4} \mathrm{CoO}_{3}$ becomes ferromagnetic while for the components with $10 \% \mathrm{Fe}$ substituted for $\mathrm{Co}$, we found an antiferromagnetic order. (c 1998 Elsevier Science B.V. All rights reserved.
\end{abstract}

Kevwords: Lanthanum cobaltites: Perovskites: Powder diffraction

\section{Introduction}

Perovskite oxides $\mathrm{ABO}_{3}$ with composition $\mathrm{La}_{1}{ }_{x} \mathrm{Sr}(\mathrm{Ba})_{x} \mathrm{CoO}_{3}$ are of industrial interest because of their electrical, magnetic and catalytic properties. Their essential application is for electrode material in solid-oxide fuel cells and as membranes in oxygen separation processes. The aim of the present work is to establish the influence of lattice distortion caused by different ionic size of substituted atoms on crystal and magnetic structure. We present data for the A- and B-sites sub-

\footnotetext{
* Corresponding author. Present address: Institut für Kristallographie, Universität Tübingen, D-72070 Tübingen, Germany. Tel.: + 49308062 2048: fax: + 493080622523 : e-mail: Sonntag $a$ hmide.
}

stituted lanthanum cobaltites $\mathrm{La}_{0.6} \mathrm{Sr}_{0.4} \mathrm{CoO}_{3}$, $\mathrm{La}_{0.6} \mathrm{Sr}_{0.4} \mathrm{Co}_{0.9} \mathrm{Fe}_{0.1} \mathrm{O}_{3}$ and $\mathrm{La}_{0.6} \mathrm{Ba}_{0.4} \mathrm{Co}_{0.9}$ $\mathrm{Fe}_{0.1} \mathrm{O}_{3}$.

\section{Experimental}

The powder samples were prepared by the citrate method. The $\mathrm{pH}$ value of the solution was kept at about $3 \pm 1$; next steps were pyrolysis at $250 \mathrm{C}$ and calcination at $1200 \mathrm{C}$ for $8 \mathrm{~h}$ in air. The singlephase quality of all samples was checked by X-ray powder diffraction. No additional phases were found.

Neutron powder diffraction experiments were performed on the flat cone diffractometer E2 and on the powder diffractometer E3 at BENSC at HMI 
Berlin. Each sample was measured at temperatures 2,300 and $900 \mathrm{~K}$. On both instruments a germanium monochromator selecting a wave- length of $\lambda=1.217 \AA(\mathrm{E} 2)$ and $\lambda=1.228 \AA$ (E3) was used.

\section{Results}

The lanthanum cobaltites $\mathrm{La}_{0.6} \mathrm{Sr}_{0.4} \mathrm{CoO}_{3}$, $\mathrm{La}_{0.6} \mathrm{Sr}_{0.4} \mathrm{Co}_{0.9} \mathrm{Fe}_{0.1} \mathrm{O}_{3}$ and $\mathrm{La}_{0.6} \mathrm{Ba}_{0.4} \mathrm{Co}_{0.9} \mathrm{Fe}_{0.1}$ $\mathrm{O}_{3}$ are rhombohedral at room temperature. They undergo a phase transition to cubic structure at

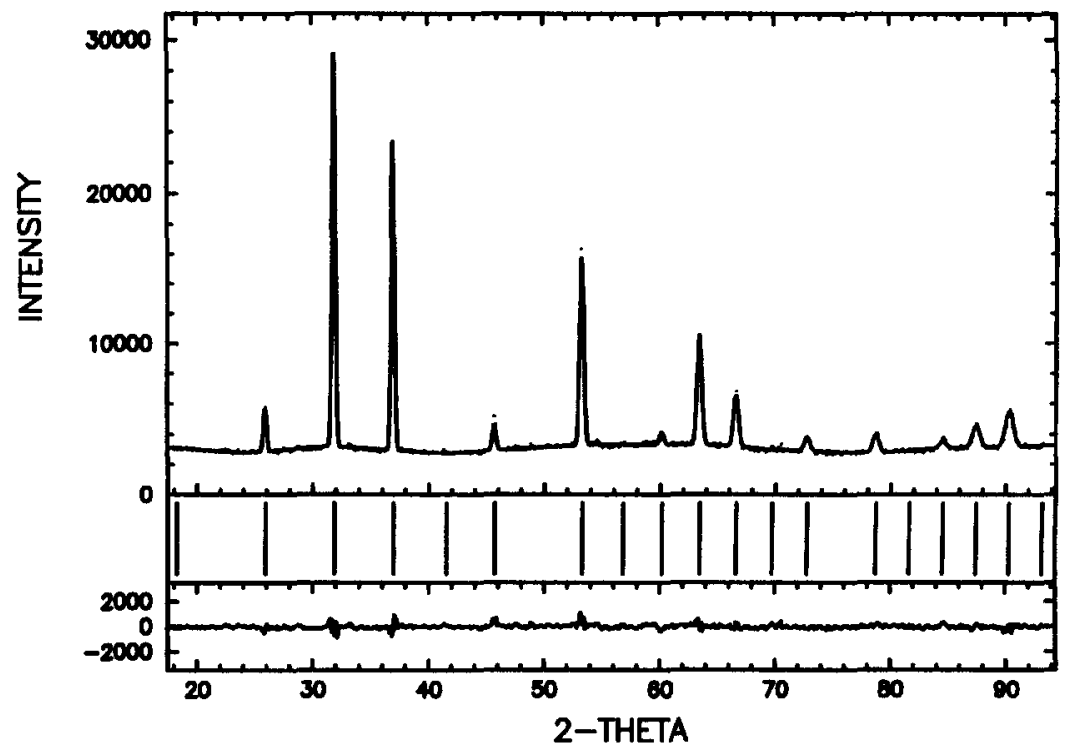

Fig. 1. Observed (circles), calculated (line) and difference plot of $\mathrm{La}_{0.6} \mathrm{Sr}_{0.4} \mathrm{CoO}_{3}$ at $T=900 \mathrm{~K}$.

Table 1

Lattice parameters, oxygen coordinates and agreement factors at $T=2,300$ and $900 \mathrm{~K}$

\begin{tabular}{|c|c|c|c|}
\hline & $\mathrm{La}_{0.6} \mathrm{Sr}_{0.4} \mathrm{CoO}_{3}$ & $\mathrm{La}_{0.6} \mathrm{Sr}_{0,4} \mathrm{Co}_{0,9} \mathrm{Fe}_{0,1} \mathrm{O}_{3}$ & $\mathrm{La}_{0.6} \mathrm{Ba}_{0.4} \mathrm{Co}_{0.9} \mathrm{Fe}_{0.1} \mathrm{O}_{3}$ \\
\hline \multicolumn{4}{|c|}{$900 \mathrm{~K}(\mathrm{Pm} 3 \mathrm{~m})$} \\
\hline$a[\AA]$ & $3.8741(3)$ & $3.8738(3)$ & $3.9216(4)$ \\
\hline$R_{\mathrm{B}}[\%]$ & 5.6 & 4.6 & 4.4 \\
\hline $300 \mathrm{~K}(\mathrm{R} 3 \mathrm{c})$ & & & $a$ \\
\hline$a[\AA]$ & $5.4518(4)$ & $5.4553(5)$ & $5.4728(8)$ \\
\hline$c[\AA]$ & $13.257(1)$ & $13.266(1)$ & $13.482(3)$ \\
\hline$O(x)$ & $0.5321(3)$ & $0.5317(4)$ & $0.514(1)$ \\
\hline$R_{\mathrm{B}}[\%]$ & 3.9 & 4.6 & 7.4 \\
\hline \multicolumn{4}{|l|}{$2 \mathrm{~K}(\mathrm{R} \overline{3} \mathrm{c})$} \\
\hline$a[\AA]$ & $5.4159(6)$ & $5.4210(8)$ & $5.4810(9)$ \\
\hline$\therefore[\AA]$ & $13.192(2)$ & $13.148(2)$ & $13.399(6)$ \\
\hline$O(x)$ & $0.5290(4)$ & $0.5334(6)$ & $0.515(1)$ \\
\hline$R_{\mathrm{B}}[\%]$ & 5.5 & 7.9 & 7.2 \\
\hline
\end{tabular}

$T=250 \mathrm{~K}$. 
temperatures around $600 \mathrm{~K}$. For example, Fig. 1 shows the neutron powder diffractogram and its refinement in cubic space group $\mathrm{Pm} 3 \mathrm{~m}$ for $\mathrm{La}_{0.6} \mathrm{Sr}_{0.4} \mathrm{CoO}_{3}$ at $900 \mathrm{~K}$. La, $\mathrm{Sr}$ and $\mathrm{Ba}$ atoms occupy the 1a site $(000)$, Co and $F e$ the $1 \mathrm{~b}$ site $\left(\frac{1}{2} \frac{1}{2} \frac{1}{2}\right)$ and oxygen the $3 \mathrm{c}$ site $\left(0 \frac{1}{2} \frac{1}{2}\right)$. All samples have rhombohedral symmetry at room temperature and at $2 \mathrm{~K}$ and were refined in space group
$\mathrm{R} \overline{3} \mathrm{c} . \mathrm{La}, \mathrm{Sr}$ and $\mathrm{Ba}$ atoms occupy the $6 \mathrm{a}$ site $\left(\begin{array}{lll}0 & 0 & \frac{1}{4}\end{array}\right)$, $\mathrm{Co}$ and $\mathrm{Fe}$ the $6 \mathrm{~b}$ site $(000)$ and oxygen the $18 \mathrm{e}$ site ( $x \quad 0 \frac{1}{4}$ ). The lattice parameters, oxygen coordinates and agreement factors for all samples are presented in Table 1.

According to [1] pure $\mathrm{LaCoO}_{3}$ is paramagnetic. The substituted $\mathrm{La}_{1}-\mathrm{Sr}_{x} \mathrm{CoO}_{3}$ becomes ferromagnetic where the transition temperature depends on

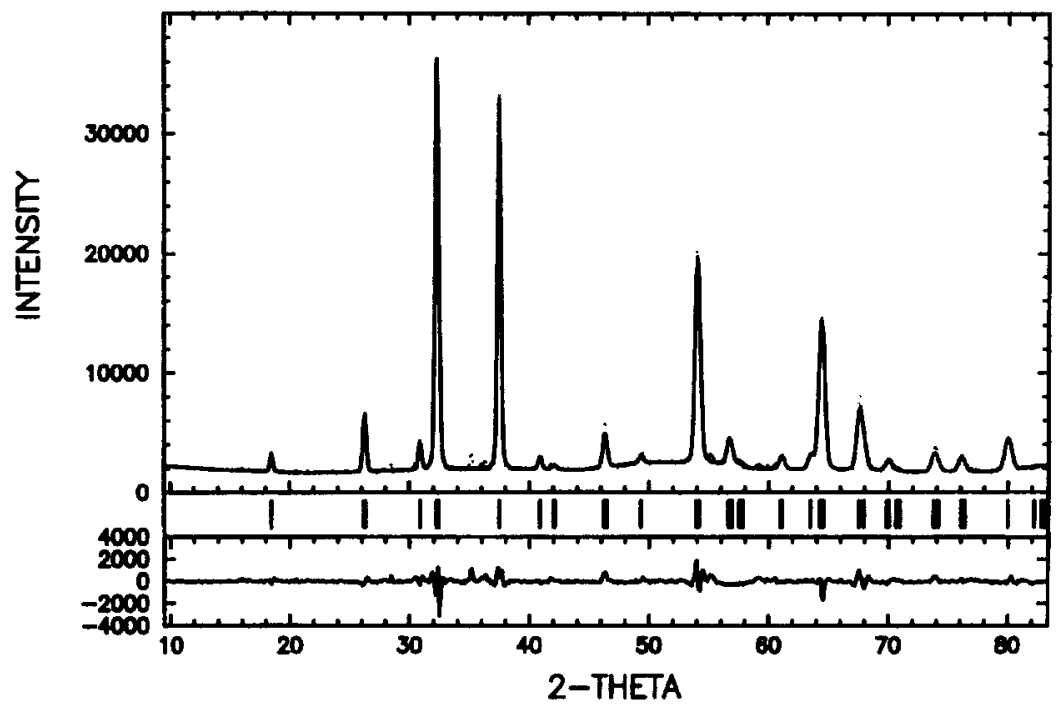

Fig. 2. Observed (circles), calculated (line) and difference plot of ferromagnetic $\mathrm{La}_{0.4} \mathrm{Sr}_{0.4} \mathrm{CoO}_{3}$ at $T=2 \mathrm{~K}$.

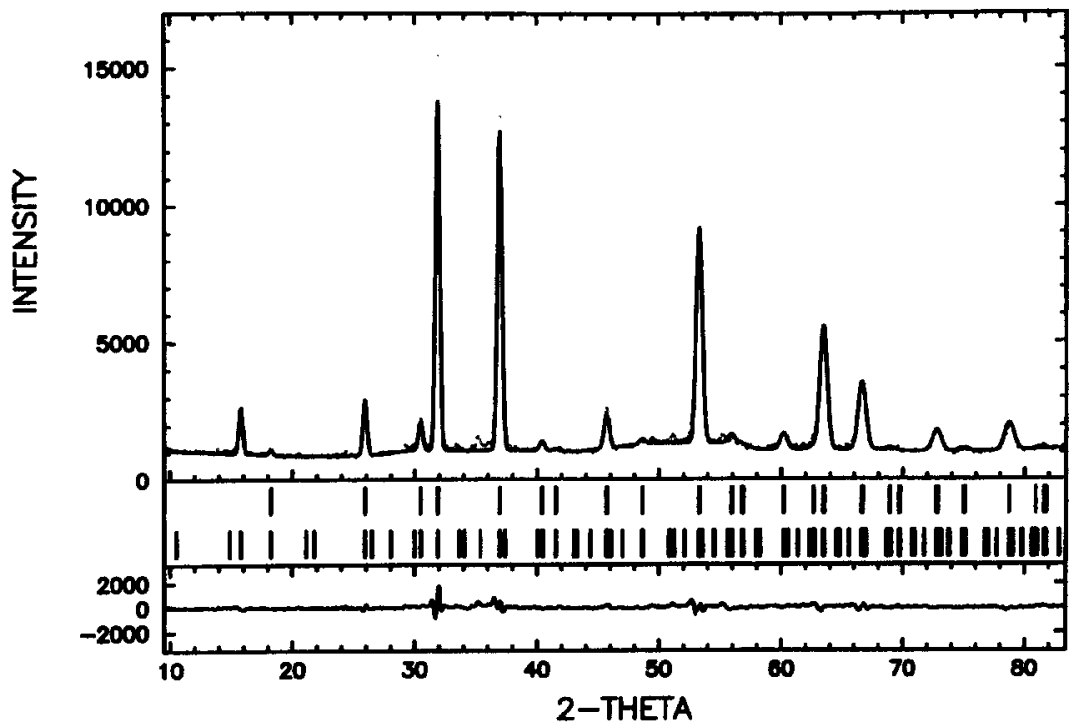

Fig. 3. Observed (circles). calculated (line) and difference plot of antiferromagnetic $\mathrm{La}_{0.6} \mathrm{Ba}_{4.4} \mathrm{Co}_{01.9} \mathrm{Fe}_{9.1} \mathrm{O}_{3}$ at $7=2 \mathrm{~K}$. 
the amount of $\mathrm{Co}^{4+}$ ions [1-3]. Fig. 2 shows the neutron powder diffractogram of ferromagnetic $\mathrm{La}_{0.6} \mathrm{Sr}_{0.4} \mathrm{CoO}_{3}$ at $2 \mathrm{~K}$. The refined average magnetic moment per Co ion is $1.35(5) \mu_{\mathrm{B}}$. The direction of the magnetic moment could not be determined from the powder data because the rhombohedral deviation from the cubic structure is small for all investigated samples.

For the B-site substituted samples an additional magnetic reflection is observed at small angle region due to antiferromagnetic ordering. The refinement for $\mathrm{La}_{0.6} \mathrm{Sr}_{0.4} \mathrm{Co}_{0.9} \mathrm{Fe}_{0.1} \mathrm{O}_{3}$ at $T=2 \mathrm{~K}$ yielded an averaged magnetic moment of 1.39(8) Bohr magnetons per $\mathrm{Co}$ atom. The replacement of $\mathrm{Sr}$ atoms by larger $\mathrm{Ba}$ atoms now leads to an increasing of the $a$ - and $c$-lattice constants as well as to an increase of the average magnetic moment per Co ion to $1.66(4) \mu_{\mathrm{B}}$ at $T=2 \mathrm{~K}$ (see Fig. 3).

The first author would like to thank Dr. Jirak for fruitful discussion about magnetic structures of perovskites. Experiments at BENSC were supported by the EC through the PECO programme (access to large-scale facilities).

\section{References}

[1] G.H. Jonker, J.H. Van Santen, Physica 19 (1953) 120.

[2] P.M. Raccah, J.B. Goodenough, J. Appl. Phys. 39 (1968) 1209.

[3] A.N. Petrov et al., Solid State Ionics 80 (1995) 189. 